\title{
KHẢO SÁT THỰC TRANG VÀ GIẢI PHÁP ĐỂ TRIỂN KHAI CÔNG TÁC DƯợC LÂM SÀNG TẠI CÁC BÊ̂NH VIỆN TRÊN ĐİA BÀN TỈNH BÌNH THUẬN
}

\author{
Lê Văn Hồng*, Ngô Minh Xuân**, Nguyễn Đăng Thoại**
}

TÓM TẮT

Mục tiêu: Nghiên cứu nhằm mục đích mô tả tình hình nhân lực y tế, quá trình thực hành dược lâm sàng và nhu câu tuyển dụng đối với dược sî̃ lâm sàng (DSLS) trong bểnh viện. Phương pháp: Điều tra cắt ngang được thực hiện trên toàn bộ 16 bệnh viện có giường bệnh tại tỉnh Bình Thuận từ tháng 6/2019 đến tháng 6/2020. Kết quả: Trong 16 bệnh viện khảo sát có $87,5 \%$ bệnh viện công chiếm $93 \%$ số giường bệnh, 50,0\% bệnh viện hạng II, 50,0\% bệnh viện hạng III, và chỉ có $1 / 16$ bệnh viện có quy mô lớn (>400 giường bênh). Toàn tỉnh Bình Thuân có 683 bác sĩ $(27,8 \%)$, 1.506 điều dưỡng $(61,3 \%)$ và 269 dược sĩ $(10,9 \%)$. Có 4,1\% số dước sĩ tại bênh viên có trình đô sau đại hoc, và chỉ có 16/269 là DSLS. Có 13/16 trưởng khoa dược bênh viên tại tỉnh Bình Thuân có nhu câu tuyển dung DSLS và đào tạo DSLS theo hình thức cho đi học để nâng cao trình độ. Kết luân: Sư thiếu hụt DSLS, nguyên nhân có thể do thu nhẩp thấp, có thể dẫn đến nhiều trở ngại cho việc cung cẩp các dịch vụ chăm sóc sức khỏe toàn diện. Vì vậy, các chiến lược tuyển dụng của bênh viên nển tâp trung vào lương và phúc lợi để thu hút nhiều DSLS, đặc biệt là những người có trình độ sau đại học.

Từ khóa: Bệnh viện, Bình Thuận, dược sĩ, dược lâm sàng, nguồn nhân lựcc.

\section{SUMMARY}

CURRENT STATUS OF CLINICAL PHARMACY WORKFORCE AND SOLUTIONS TO IMPLEMENT CLINICAL PHARMACY IN BINH THUAN PROVINCE

Objectives:The study aims to describe the health human resources situation, clinical pharmacy practice and recruitment demand for clinical pharmacists (CPs) in hospitals. Method: The cross-sectional study was conducted in all 16 hospitals with patient beds in Binh Thuan province from June 2019 to June 2020. Results: Of the 16 hospitals, $87.5 \%$ of public hospitals account for $93 \%$ of hospital beds, $50.0 \%$ of grade II hospitals, $50.0 \%$ of grade III hospitals, and only $1 / 16$ large hospital (> 400 hospital beds). Binh Thuan province has 683 doctors $(27.8 \%), 1,506$ nurses (61.3\%) and 269 pharmacists (10.9\%). 4.1\% of the pharmacists at the hospital have postgraduate degrees, and only $16 / 269$ are CPs. There are $13 / 16$ Heads/Deputy heads of Department of Pharmacy in

$* *$

Chịu trách nhiệm chính:

Email:

Ngày nhận bài:

Ngày phản biện khoa học:

Ngày duyệt bài:
Binh Thuan province wishing to recruit CPs and they suggest training CPs by assigning CPs on continuing education to improve their qualifications. Conclusion: A deficiency of CPs can be because of the low income; it's leads to many obstacles to the provision of health care services. Therefore, hospital recruitment strategies should focus on salaries and benefits to attract more CPs, especially those with graduate degrees.

Keywords: Binh Thuan, clinical pharmacy, hospital, human resources, pharmacist.

\section{I. ĐẶT VẤN ĐỀ}

Dược lâm sàng (DLS) là một bô môn khoa học sức khỏe và dịch vụ của dược sĩ lâm sàng để phát triển và thúc đẩy việc sử dụng thuốc hợp lý, an toàn và hiệu quả. Dược sĩ lâm sàng (DSLS) chịu trách nhiệm tối ưu hóa việc sử dụng thuốc, giảm thiểu rủi ro và gia tăng hiệu quả - chi phí liên quan đến việc sử dụng thuốc. Nghiên cứu củaKlopotowska cùng cộng sự (2010) tại Hà Lan cho thấy tỷ lệ kê đơn sai sót trong một ngày trên 1.000 người bệnhđược theo dõi giảm đáng kể từ 190,5 xuống $62,5(P<0,001)$ sau khi có can thiệp của các hoạt động DLS. Một nghiên cứu DLS thực hiện từ tháng 10-12/2013 tại Ý trên 94 người bệnh trên 70 tuổi ghi nhận 740 can thiệp được thực hiện. Khoảng $12 \%$ các trường hợp là do bác sĩ viết sai tên thuốc hoặc liêu lượng, chủ yếu trên các đơn có kê kháng sinh toàn thân và thuốc điều trị Parkinson, 93,2\% các can thiệp DLS đều được các bác sĩ chấp thuận. Sau khi đánh giá tổng quát, $63,2 \%$ các can thiệp được đánh giá là có hiệu quả lâm sàng trung bình, $23,4 \%$ có hiệu quả lâm sàng cao. Ngoài ra, mộtnghiên cứu ở Trung Quốc cho thây DLS đã góp phần đáng kể vào tỷ lệ tăng tuân thủ thuốc $(70,17-81,41 \%)$ trong các phác đồ điều trị, và giảm thời gian nằm viện (10,83-6,45 ngày) của người bệnh. Tuy nhiên, việc triển khai DLS cũng như hiệu quả mang lại rất khác nhau giữa các quốc gia, tùy thuộc vào tình trạng kinh tế xã hội khác nhau. Ví dụ, so với châu Âu, các dịch vụ dược lâm sàng đã nhiều hơn thường được thực hiện ở Hoa Kỳ[1]. Các dịch vụ dược lâm sàng đã phổ biến hơn ở các nước phát triển, nhưng nó vẫn trong giai đoạn đầu giữa các nước đang phát triển trong đó có Việt Nam.

Hiện nay, trên địa bàn tỉnh Bình Thuân có 16 bệnh viện công lập (kể cả Trung tâm Y tế thực hiện hai chức năng) và tư nhân trực thuộc Sở Y tế, tổng số giường bệnh tính đênn năm 2017 là 
3.135 giường, trong đó số giường bệnh tuyến tỉnh là 1.945 giường (chưa tính giường bệnh tại Trạm Y tế xã). Tổng số cán bộ chuyên môn ngành Dược năm 2017 là 597 người, trong đó chỉ có 83 người có trình độ đại học và sau đại học, tỷ lệ chỉ đạt 0,54 Dược sĩ/10.000 dân. Số lượng nhân lực có chuyên môn hạn chế là một trong những nguyên nhân khiến cho công tác quản lý thuốc, đặc biệt là công tác DLS tại các cơ sở điều trị gặp nhiều khó khăn [2]. Theo quy hoạch phát triển ngành $Y$ tế tỉnh Bình Thuận đến năm 2020,100\% khoa Dược của các bệnh viện phải có DSĐH chuyên trách làm công tác DLS, trên $90 \%$ số cơ sở khám chữa bệnh phải thực hành tốt hoạt động tư vấn DLS đến năm 2020 và đến năm 2030 là 100\% [3]. Do đó, nghiên cứu này nhằm khảo sát, phân tích hiện trạng của lực lượng lao động và các hoạt động của cơ quan y tế về hoạt động dược lâm sàng, cũng như nhu cầu tuyển dụng DSLS tại các bệnh viện ở tỉnh Bình Thuận.

\section{II. ĐỐI TƯợNG VÀ PHƯƠNG PHÁP NGHIÊN CỨU}

2.1. Đối tượng nghiên cứu: Các bệnh viện có giường bệnh tại tỉnh Bình Thuận.

Thời gian nghiên cứu: Tháng 06/2019- 06/2020.

2.2. Phương pháp nghiên cứu: Nghiên cứu mô tả cắt ngang, lấy mẫu toàn bộ để khảo nguồn nhân lực y tế trên địa bàn tỉnh Bình Thuận.

2.3. Nội dung nghiên cứu: Khỏa sát nguồn nhân lực y tế tại tỉnh Bình Thuận và nhu cầu tuyển dược sĩ lâm sàng tại các bệnh viện trong tỉnh.

2.4. Phân tích dữ liệu: Các số liệu trong đề tài được thống kê theo từng tiêu chí nghiên cứu các biến định tính được trình bày dưới dạng số lượng, tỷ lệ phần trăm, kết quả nghiên cứu được trình bày dưới dạng bảng, biểu đồ và hình vẽ bằng phần mềm Microsoft Excel 2016.

\section{KẾT QUẢ NGHIÊN CứU}

3.1. Đặc điểm các bệnh viện được khảo sát tại tỉnh Bình Thuận

Bảng 1. Thống kê các bệnh viện được khảo sát tại tỉnh Binh Thuận

\begin{tabular}{|c|c|c|}
\hline Biến & Số lượng & $\mathbf{\%}$ \\
\hline Số giường bệnh (Giường) & 3.523 & \\
\hline Trung bình (Độ lệch chuấn) & 220,2 & 203,6 \\
\hline Thấp nhẫt - Cao nhất & $40-910$ & \\
\hline Loại hình: Công & 14 & 87,5 \\
\hline Tư & 2 & 12,5 \\
\hline Phân hạng: Hạng II & 8 & 50,0 \\
\hline Hạng III & 8 & 50,0 \\
\hline Chức năng: Đa khoa & 6 & 37,5 \\
\hline Chuyên khoa & 3 & 18,75 \\
\hline Trung tâm y tế hai chức năng & 7 & 43,75 \\
\hline
\end{tabular}

\begin{tabular}{|c|c|c|}
\hline Quy mô bệnh viện: Nhỏ & 5 & 31,25 \\
\hline Trung bình & 10 & 62,5 \\
\hline Lớn & 1 & 6,25 \\
\hline Tống & $\mathbf{1 6}$ & $\mathbf{1 0 0 , 0}$ \\
\hline
\end{tabular}

Bảng 1 cho thấy các đặc điểm của các bệnh viện đã khảo sát tại tỉnh Bình Thuận phân theo loại hình bệnh viện, phân hạng bệnh viện, chức năng bệnh viện và quy mô bệnh viện. Trong đó các bệnh viện chủ yếu là các bệnh viện công, tổng số giường bênh trong tỉnh là 3.523 giường bệnh. Trong đó chủ yếu là các bệnh viện công lập $(87,5 \%)$, các bệnh viện có quy mô trung bình (62,5\%), chỉ có một bệnh viện có quy mô lớn.

3.2. Nguồn nhân lực y tế của các bệnh viện. Khảo sát cho thấy trên địa bàn tỉnh Bình Thuận có số lượng nhân viên y tể bao gồm bác sĩ, điều dưỡng và dược sĩ lần lượt là $683(27,8 \%)$, $1.506(61,2 \%)$ và $269(10,9 \%)$. Tỷ lệ bác sĩ/điêu dưỡng/dược sĩ là 2,55/5,64/1,0. Các bệnh viện công chiếm hơn $85 \%$ số nhân viên y tế trong toàn tỉnh (Bảng 2). Nghiên cứu còn cho thây tỷ lệ trung bình của các dược sĩ có trình độ đại học, sau đại học với bác sĩ và tổng số dược sĩ lần lượt là 0,13 và 0,33 (Bảng 3).

3.3. Các kỹ năng của DSLS. Trong tất cả các kỹ năng chuyên môn của DSLS tại bệnh viện cho thấy, DSLS rất quan tâm đến ngoại ngữ với $3,9 \pm 0,7$ điểm. Tuy nhiên kỹ năng tìm kiếm và sử dụng thông tin và kỹ năng tự học nâng cao trình độ chuyên môn lại có điểm thấp hơn với số điểm lần lượt là $3,2 \pm 1,0$ và $3,2 \pm 0,9$ điểm.

Về kỹ năng mềm của DSLS, điểm trung bình

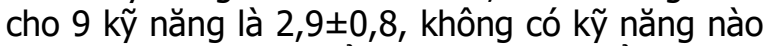
nằm ở mức Tốt (4 điểm), Rất tốt (5 điểm). Có 4 kỹ năng đạt điểm trung bình cao nhất $3,2 \pm 0,9$ là: Giải quyết tình huống công việc thực tế; làm việc độc lập, sáng tạo; bày tỏ ý kiến, quan điểm cá nhần; chịu áp lực công việc. Kỹ năng có điểm trung bình thấp nhất là tuân thủ kỉ luật lao động 2,3 $\pm 0,8$ (Bảng4).

Bảng 2. Nguồn nhân lực y tế của các bệnh viện trên địa bàn tỉnh Bình Thuận

\begin{tabular}{|c|c|c|c|}
\hline Chỉ số & $\begin{array}{c}\text { Bác sĩ } \\
(\%)\end{array}$ & $\begin{array}{c}\text { Điều } \\
\text { dưỡng(\%) }\end{array}$ & $\begin{array}{c}\text { Dược sĩ } \\
(\%)\end{array}$ \\
\hline \multicolumn{4}{|c|}{ Loại hình } \\
\hline Công & $586(85,8)$ & $1.344(89,2)$ & $238(88,5)$ \\
\hline Tư & $97(14,2)$ & $162(10,8)$ & $31(11,5)$ \\
\hline \multicolumn{4}{|c|}{ Phân hạng } \\
\hline Hạng II & $415(60,8)$ & $997(66,2)$ & $147(54,6)$ \\
\hline Hạng III & $268(39,2)$ & $509(33,8)$ & $122(45,4)$ \\
\hline \multicolumn{4}{|c|}{ Chức năng } \\
\hline Đa khoa & $387(56,7)$ & $907(60,2)$ & $130(48,3)$ \\
\hline Chuyên khoa & $58(8,5)$ & $122(8,1)$ & $27(10,0)$ \\
\hline
\end{tabular}




\begin{tabular}{|c|c|c|c|}
\hline $\begin{array}{c}\text { Trung tâm } \\
\text { y tế hai chức } \\
\text { năng }\end{array}$ & $\begin{array}{c}238 \\
(34,8)\end{array}$ & $\begin{array}{c}477 \\
(31,7)\end{array}$ & $\begin{array}{c}112 \\
(41,6)\end{array}$ \\
\hline \multicolumn{4}{|c|}{ Quy mố } \\
\hline Nhỏ & $100(14,6)$ & $187(12,4)$ & $58(21,6)$ \\
\hline
\end{tabular}

\begin{tabular}{|c|c|c|c|}
\hline Trung bình & $448(65,6)$ & $927(61,6)$ & $175(65,1)$ \\
\hline Lớn & $135(19,8)$ & $392(26,0)$ & $36(13,4)$ \\
\hline Tổng & $\mathbf{6 8 3}$ & $\mathbf{1 . 5 0 6}$ & $\mathbf{2 6 9}$ \\
& $\mathbf{( 2 7 , 8 )}$ & $\mathbf{( 6 1 , 2 )}$ & $\mathbf{( 1 0 , 9 )}$ \\
\hline
\end{tabular}

Bảng 3. Nguồn nhân lực Dược tại các bệnh viện trên địa bàn tỉnh Bỉnh Thuận

\begin{tabular}{|c|c|c|c|c|c|c|c|c|}
\hline Chỉ số & DSSĐH & DSĐH & DSCĐ & DSTH & DSC & $\begin{array}{l}\text { Số lượng } \\
\text { DSLS }\end{array}$ & $\begin{array}{c}\text { (SĐH+ } \\
\text { ÐH) / BS }\end{array}$ & $\begin{array}{l}\text { (SĐH+ } \\
\text { ĐH)/DS }\end{array}$ \\
\hline \multicolumn{9}{|l|}{ Loại hình } \\
\hline Công & $10(4,2)$ & $72(30,3)$ & $69(29,0)$ & $81(34,0)$ & $6(2,5)$ & 12 & 0,08 & 0,34 \\
\hline Tư & $1(3,2)$ & $7(22,6)$ & $7(22,6)$ & $16(51,6)$ & - & 4 & 0,12 & 0,26 \\
\hline \multicolumn{9}{|l|}{ Phân hạng } \\
\hline Hang II & $10(6,8)$ & $46(31,3)$ & $23(15,6)$ & $63(42,9)$ & $5(3,4)$ & 15 & 0,13 & 0,38 \\
\hline Hạng III & $1(0,8)$ & $33(27)$ & $53(43,4)$ & $34(27,9)$ & $1(0,8)$ & 1 & 0,13 & 0,28 \\
\hline \multicolumn{9}{|l|}{ Chức năng } \\
\hline Đa khoa & $10(5,6)$ & $35(19,4)$ & $24(13,3)$ & $58(32,2)$ & $3(1,7)$ & 14 & 0,15 & 0,26 \\
\hline Chuyên khoa & $1(0,6)$ & $11(6,1)$ & $5(2,8)$ & $8(4,4)$ & $2(1,1)$ & 1 & 0,14 & 0,35 \\
\hline $\begin{array}{c}\text { Trung tâm } \\
\text { y tế hai chức năng }\end{array}$ & - & $33(18,3)$ & $47(26,1)$ & $31(17,2)$ & $1(0,6)$ & 1 & 0,10 & 0,36 \\
\hline \multicolumn{9}{|l|}{ Quy mô } \\
\hline Nho & $2(1,1)$ & $13(7,2)$ & $15(8,3)$ & $27(15)$ & $1(0,6)$ & 1 & 0,15 & 0,26 \\
\hline Trung bình & $6(3,3)$ & $56(31,1)$ & $60(33,3)$ & $50(27,8)$ & $3(1,7)$ & 14 & 0,14 & 0,35 \\
\hline Lớn & $3(1,7)$ & $10(5,6)$ & $1(0,6)$ & $20(11,1)$ & $2(1,1)$ & 1 & 0,10 & 0,36 \\
\hline Tổng & $\begin{array}{c}11 \\
(6,1)\end{array}$ & $\begin{array}{c}79 \\
(43,9)\end{array}$ & $\begin{array}{c}76 \\
(42,2)\end{array}$ & $\begin{array}{c}97 \\
(53,9)\end{array}$ & $\begin{array}{c}6 \\
(3,3)\end{array}$ & 16 & 0,13 & 0,33 \\
\hline
\end{tabular}

Ghi chú: DSSĐH: Dược sĩ sau đại học, DSĐH: Dược sĩ đại học, DSCĐ: Dược sĩ cao đằng, DSTH: Dược sĩ trung học, DSC: Dược sĩ sơ cấp, DSLS: Dược sĩ lâm sàng, SĐH: Sau đại học, ĐH: Đại học, BS: Bác sĩ, DS: Dược sĩ

Bảng 4. Tổng quát kỹ năng chuyên môn của DSLS tại tất cả bệnh viện đã khảo sát

\begin{tabular}{|c|c|c|c|c|}
\hline 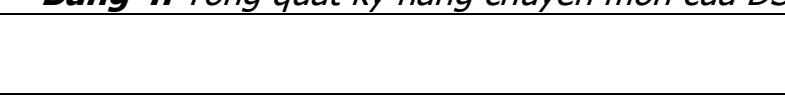 & $\begin{array}{l}\text { Trung } \\
\text { bình }\end{array}$ & $\begin{array}{l}\text { Độ lệ̂ch } \\
\text { chuẩn }\end{array}$ & $\begin{array}{c}\text { Điếm thấp } \\
\text { nhất }\end{array}$ & $\begin{array}{c}\text { Điểm cao } \\
\text { nhất }\end{array}$ \\
\hline \multicolumn{5}{|l|}{ Các kỹ năng chuyên môn } \\
\hline 1. Thực hành chuyên môn nghiệp vụ & 3,5 & 1,0 & 2,0 & 5,0 \\
\hline 2. Tìm kiếm và sử dụng thông tin & 3,2 & 1,0 & 2,0 & 5,0 \\
\hline 3. Tự kiểm tra và đánh giá công việc & 3,3 & 1,1 & 2,0 & 5,0 \\
\hline 4. Sử dụng ngoại ngữ & 3,9 & 0,7 & 3,0 & 5,0 \\
\hline 5. Tự học nâng cao trình độ chuyên môn & 3,2 & 0,9 & 2,0 & 5,0 \\
\hline Điểm TB kỹ năng chuyên môn & 3,4 & 0,9 & 2,0 & 5,0 \\
\hline \multicolumn{5}{|l|}{ Các kỹ năng mềm } \\
\hline 1. Giải quyết tình huống công việc thực tế & 3,2 & 0,9 & 2,0 & 5,0 \\
\hline 2. Làm việc độc lập, sáng tạo & 3,2 & 0,9 & 2,0 & 5,0 \\
\hline $\begin{array}{l}\text { 3. Tiếp thu, lắng nghe các góp ý và giải quyết các } \\
\text { bất đồng }\end{array}$ & 3,0 & 0,9 & 2,0 & 5,0 \\
\hline 4. Bày tỏ ý kiến, quan điểm cá nhân & 3,2 & 0,8 & 2,0 & 5,0 \\
\hline 5. Chịu áp lực công việc & 3,2 & 0,9 & 2,0 & 5,0 \\
\hline 6. Nhiệt tình trong công việc & 2,6 & 0,7 & 2,0 & 4,0 \\
\hline 7. Hiếu biết về xã hội và pháp luật & 2,7 & 0,7 & 2,0 & 4,0 \\
\hline 8. Tuân thủ kỷ luật lao động & 2,3 & 0,8 & 1,0 & 4,0 \\
\hline 9. Tham gia các hoạt động xã hội & 2,4 & 0,9 & 1,0 & 4,0 \\
\hline Điểm TB kỹ năng mềm & 2,9 & 0,8 & 1,0 & 5,0 \\
\hline
\end{tabular}

Hình 1 cho thấy có nhu cầu tuyển DSLS có 13/16 Ban lãnh đạo các Khoa dược tại các bệnh viện muốn tuyển DSLS. Bên cạnh đó, Ban giám đốc và Phòng Tổ chức - cán bộ có sự đồng thuận cao trong vấn đề tuyển DSLS với số lượng như nhau. 

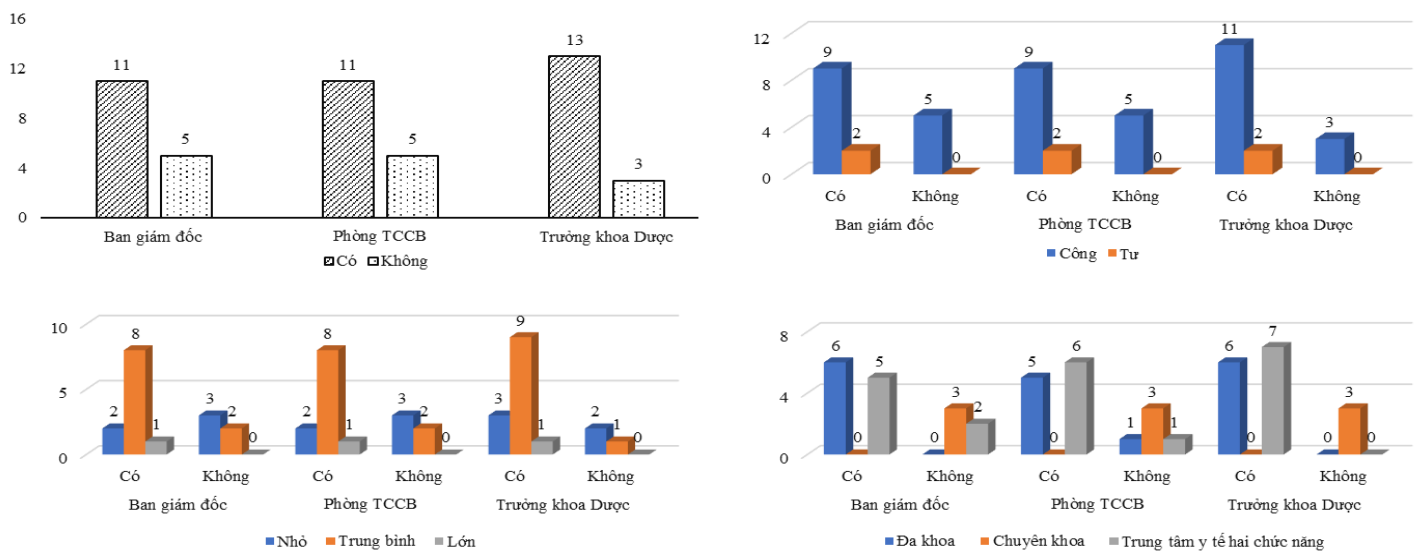

Hình 1. Nhu cầu tuyển Dược sĩ dược lâm sàng tại các bệnh viện

\section{BÀN LUẬN}

Khảo sát được thực hiên trên tất cả 16 bênh viện có giường bệnh tại tỉnh Bình Thuận đã đại diện cho tình hình nhần lực y tế tại tỉnh Bình Thuân. Các số liệu này cho thấy tình hình nhân lực y tế của tỉnh Bình Thuận cũng như nhu cầu thực tế của của các bệnh viện trong điều kiện hiện nay. Phần lớn bệnh viện tại tỉnh Bình Thuận có quy mô nhỏ, chủ yếu là bệnh viện đa khoa, đa số là bệnh viện công và các bệnh viện thuộc bệnh viện hạng II và hạng III chiếm tỉ lệ cao.

4.1. Thực trạng cở cấu nguồn nhân lực y tế tại Tỉnh Bình Thuân. Nhóm dược sĩ chiếm khoảng $11 \%$ toàn bộ nhân lực về y tế chủ chốt của bệnh viên, với khoảng hơn 269 dược sĩ tuy nhiên con số này đều rất thấp so với nhóm điều dưỡng (gấp khoảng 6 lần số dược sĩ) hoặc bác sĩ (gấp 2,5 lần dược sĩ) trong bệnh viện. Con số này cũng tương đương với con số ở một số tỉnh thành khác tại Việt Nam, như Cà Mau với tỷ lệ $D S Đ H$ và $D S S Đ H$ so với $B S$ là $1 / 7$ [4]. Con số này cũng tương ứng với con số thiếu hụt về nhân lực dược trên toàn quốc [5].

Lực lượng nhân viên y tế chủ chốt (bác sĩ, điêu dưỡng, dược sĩ) ở nhóm bệnh viện công cao hơn nhóm bệnh viện tư ở tất cả các nhóm. Điều này cũng hợp lý so với số lượng bệnh viện tư nhân /công lập tại bệnh viện. Đối với điều dưỡng và bác sĩ, phần lớn nhân lực tập trung ở các bệnh viện hạng II và hạng III, trong đó tại tỉnh Bình Thuận không có bệnh viện hạng I nào. Bệnh viện hạng II chiếm khoảng $60 \%$ số nhân lực của tỉnh.

Riêng đối với nhóm dược sĩ, nhóm có trình độ đại học trở lên chỉ chiếm khoảng một phần ba so với toàn bộ dược sĩ làm việc trong bệnh viện. Ở các bệnh viện dù đa khoa hay chuyên khoa, bệnh viện quy mô nhỏ, trung bình hay lớn, dù bênh viện là hang II, III thì nhóm nhân lực trình độ cao này cũng có tỷ lệ rất thấp so với toàn bộ dược sĩ bệnh viện, hay so với bác sĩ bệnh viện. Đây cũng có thể là một yếu tố cần cân nhắc trong quá trình xem xét khi muốn phát triển nguồn nhân lực dược lâm sàng tại bệnh viện.

4.2. Nguồn nhân lực dược lâm sàng của các bệnh viện tại tỉnh Bình Thuận. Tính đến 06/2020 mới chỉ có $10 / 16$ bệnh viện khảo sát có dược sĩ lâm sàng. Tuy nhiên, số lượng các dược sĩ lâm sàng tại các bệnh viện cũng rất hạn chế với tổng cộng 16 dược sĩ lâm sàng. Ở các bệnh viện có $D S L S$, phần lớn lại là các dược sĩ mới tuyển vào trình đô là đai học do nhu cầu thực tế và Luật Dược 2016 và Nghị định 131/2020. Đồng thời số lượng dược sĩ có trình độ rất cao (như TS hoặc CK2) lại rất thấp hoặc không có dược sĩ CK2. Đặc biệt là các bệnh viện chuyên khoa tham gia trong khảo sát không có nguồn nhân lực chất lượng cao như CK2 hay TS. Điều này cũng tương tự như các kết quả trước về số lượng và chuyên môn của DLS của tác giả Hieu Trinh và cộng sự[6].

4.3. Một số hạn chế của đề tài. Khảo sát được thực hiện trên 16 bệnh viện, tuy nhiên, khảo sát này không thu thập được mẫu từ các Trung tâm y tế một chức năng (03 đơn vị) do đây là các cơ sở y tế không thực hiện chức năng khám chữa bệnh (không có giường bệnh) (nhóm này là các trung tâm y tế của các xã số lượng nhân viên y tế cũng như giường bệnh rất ít). Tuy vậy, kết quả của khảo sát này không nói lên được toàn bộ nhân viên y tế trên địa bàn tỉnh Bình Thuận.

\section{KẾT LUÂNN}

Nghiên cứu này cung cấp một cái nhìn tổng quan về nhân lực y tế của tỉnh Bình Thuận nói chung và nhân lực DLS nói riêng, ngoài ra hoạt 
động DLS và nhu cầu tuyển dụng tại các bệnh viện ở tỉnh Bình Thuận. Kết quả chỉ ra tình trạng thiếu hụt DSLS ở tỉnh Bình Thuận, đặc biệt là những người có trình đô học vấn cao, nguyên nhân có thể là do thu nhập thấp. Nghiên cứu đề xuất rằng các bệnh viện nên hồ trợ về thu nhập như lương, trợ cấp nghề nghiệp để thu hút nhiều dược sĩ là công tác DLS hơn và liên tục nâng cao chuyên môn của họ cho công việc. Ngoài ra, kết quả của nghiên cứu này có thể được sử dụng để hỗ trợ cho báo cáo của Sở Y tế tỉnh Bình Thuận gửi Bộ $Y$ tế và đề xuất các chính sách ngắn hạn và dài hạn nhằm cải thiện thực hành dược lâm sàng ở Việt Nam.

\section{TÀI LIÊU THAM KHẢO}

1. Pawłowska, I., et al., Clinical and conventional pharmacy services in Polish hospitals: a national survey. Int J Clin Pharm, 2016. 38(2): p. 271-9.

2. Sở Y tế tỉnh Bình Thuận. Hiện trạng khám chữa bênh tỉnh Bình Thuân năm 2017. 2018 [cited 2019 6/6]; Available from: http:// syt.binhthuan.gov.vn/ wps/portal/binhthuan/ trangchu/!ut/p/c5/ 04_SB8K8xLLM9MSSzPy8xBz9CP0os3gfDxCLQ2MD Q09_Xy9XA0f3ED8nswB3YzNLQ_1wkA48Kowg8gY 4gKÖBvp9Hfm6qfkF2dpqjo6IiAO-

LHHI!/dl3/d3/L2dBISEvZOFBIS9nQSEh/.

3. Ủy ban Nhân dân tỉnh Bình Thuận, Quyết định số 2881/QĐ-UBND về quy hoạch phát triển Ngành Y tế tỉnh Bình Thuân đến năm 2020 2011, ngày 29 tháng 12 năm 2011: Bình Thuận.

4. Bệnh viện đa khoa Cái Nước. Nghiên thực trạng nhân lực dược tại các cơ sở y tế công lập tỉnh Cà Mau nẳm 2013 và nhu câu đến năm 2016. 2014 [cited 11/10/2020; Available from: http:// cainuochospital.com/ nghien-cuu-thuc-trang-nhanluc-duoc-tai-cac-co-so-y-te-cong-lap-tinh-ca-maunam-2013-va-nhu-cau-den-nam-2016.html.

5. Vo, T.-H., et al., Pharmacy Education in Vietnam. Vol. 77. 2013. 114.

6. Trinh, H.T., et al., Hospital clinical pharmacy services in Vietnam. Int J Clin Pharm, 2018. 40(5): p. $1144-1153$.

\title{
TÁC DỤNG GÂY HOẠI TỬ TẾ BÀO UNG THƯ CỦA VIRUS VACCIN SỞI VÀ NIMOTUZUMAB
}

\author{
Cấn Văn Mão', Lê Mạnh Cường ${ }^{2}$, Hồ Anh Sơnn ${ }^{1}$
}

\section{TÓM TẮT}

Mục tiêu: Đánh giá hiệu quả virus vaccin sởi (MeV) và Nimotuzumab gây chết kiểu hoại tử trên tế bào ung thư. Đối tượng và phương pháp: Sử dụng MeV và Nimotuzumab gây chết tế bào ung thư Hep2. Tế bào Hep2 tiếp xúc MeV và Nimotuzumab được thu thập ở thời điểm 48 giờ, 72 giờ, 96 giờ để đánh giá bằng kỹ thuât flow cytometry. Kết quả: Tỉ lệ tế bào chết kiểu hoại tử ở các nhóm điều trị nhiêu hơn có nghĩa thống kê so với nhóm chứng, thời điểm 96h, kết hợp MeV và Nimotuzumab gây chết tế bào ung thư kiểu hoại tử nhiều hơn so với dùng đơn. Kết luận: kết hợp virus vaccine sởi và Nimotuzumab có tác dụng gẩy chết tế bào Hep2 kiểu hoại tử nhiêuu hơn dùng đơn virus vaccine sởi hoặc Nimotuzumab.

Ti̛ khóa: Ung thư đầu cổ, virus vaccine sởi, Nimotuzumab, chết hoại tử

\section{SUMMARY \\ NECROSIS EFFECTS OF VACINE-STRAIN \\ MEASLES VIRUS AND NIMOTUZUMAB ON CANCER CELLS}

Objectives: This study aims to evaluate of

\footnotetext{
${ }^{1}$ Học viện Quân y

${ }^{2}$ Bềnh viên YHCT Trung ương

Chịu trách nhiệm chính: Hồ Anh Sơn

Email: hoanhsonhp@gmail.com

Ngày nhận bài: 11/11/2020

Ngày phản biện khoa học: 3/12/2020

Ngày duyệt bài: 16/12/2020
}

necrosis effects of vacine-strain measles virus (MeV) and Nimotuzumab against cancer cells. Materials and methods: MeV and Ninotuzumab were used to induce necrosis on Hep2 cancer cells. Hep2 cells treated with MeV and Nimotuzumab were collected at 48, 72 hours and 96 hours to perform flow cytometry. Results: the proportion of necrosis cells in treated groups was significantly higher than control group. $\mathrm{MeV}$ and Nimotuzumab combination induced higher rate of necrosis cells than thouse in single treatment groups. Conclusion: MeV and Nimotuzumab combination increases necrosis on head and neck cancer Hep2 cells than single MeV or Nimotuzumab treatment.

Keywords: head and neck squamous-cell carcinoma, measles virus vaccine, Nimotuzumab, necrosis.

\section{I. ĐĂT VẤN ĐỀ}

Ung thư đầu cổ là một nhóm bệnh ung thư xuất phát từ những vị trí khác nhau ở đường hô hấp và tiêu hoá trên. Những ung thư này có nhiều điểm chung về sinh bệnh học, dịch tễ, lâm sàng và điều trị. Hầu hết các khối u ác tính vùng đầu cổ xuất phát từ biểu mô bề mặt nên có tới hơn $90 \%$ số trường hợp là ung thư biểu mô tế bào vảy hoặc các biến thể của nó. Hơn $90 \%$ ung thư đầu cổ có bộc lộ thụ thể tăng trưởng biểu bì (EGFR), liên quan tới tình trạng đáp ứng kém với hóa, xạ trị1. EGFR thường biểu hiện quá mức và đóng vai trò quan trọng trong bênh sinh của ung thư đầu cổ. Đặc biệt, sự biểu hiện của EGFR tăng cao trong các khối u trong giai đoạn tiến 